\title{
Konsumsi Sayur dan Buah pada Siswa SMP sebagai Implementasi Pedoman Gizi Seimbang
}

\section{Vegetables and Fruits Consumption in Junior High School Student as the Implementation of Indonesian Balanced-Nutrition Guidelines}

\author{
Fitriyah Nafsiyah Muthmainah*, Ali Khomsan, Hadi Riyadi, Guntari Prasetya \\ Departemen Gizi Masyarakat, Fakultas Ekologi Manusia, Institut Pertanian Bogor \\ ("fitriyahnm01@gmail.com,087870917644)
}

\begin{abstract}
ABSTRAK
Indonesia dihadapkan pada dua masalah gizi yaitu gizi kurang dan gizi lebih sedangkan permasalahan gizi pada remaja cenderung lebih dominan untuk mengalami kelebihan berat badan, ini dapat dilihat dari prevalensi sangat gemuk (obesitas) remaja di Kabupaten Cianjur sebesar 10.6\%. Oleh karena itu, konsumsi sayur dan buahbuahan sangat dianjurkan untuk menurunkan prevalensi kelebihan berat badan khususnya pada remaja. Pemerintah melalui Pedoman Gizi Seimbang menganjurkan konsumsi sayuran dan buah-buahan sejumlah 400 g per orang per hari yang terdiri dari $250 \mathrm{~g}$ sayur dan $150 \mathrm{~g}$ buah. Tujuan dari penelitian ini adalah mengidentifikasi ketersediaan sayur dan buah di rumah, kontribusi sayur dan buah terhadap asupan vitamin, mineral dan serat dan hubungan antara praktik gizi siswa maupun ibu sebagai orang tua siswa terkait pedoman gizi seimbang dengan konsumsi sayur dan buah siswa. Penelitian ini merupakan penelitian cross-sectional yang didanai oleh Neys-van Hoogstraten Foundation, the Netherlands dan dilakukan di SMPN 1 Cianjur dengan total subjek penelitian berjumlah 72 siswa. Data dianalisis menggunakan uji beda Mann Whitney dan uji hubungan Rank Spearman. Jumlah konsumsi sayur dan buah siswa belum sesuai dengan anjuran Pedoman Gizi Seimbang. Konsumsi sayur siswa dengan rata-rata $36.9 \pm 34.8 \mathrm{~g}$ per hari, sedangkan konsumsi buah siswa dengan rata-rata $203.2 \pm 112.9 \mathrm{~g}$ per hari. Terdapat hubungan yang signifikan $(p<0.05)$ antara praktik gizi ibu serta praktik gizi siswa terkait PGS dengan konsumsi sayur dan buah siswa. Penelitian ini menunjukkan bahwa konsumsi sayur dan buah pada siswa belum terimplementasikan sesuai dengan anjuran Pedoman Gizi Seimbang sehingga perlu adanya dorongan kepada orangtua dalam rangka meningkatkan konsumsi sayur dan buah yang dapat memotivasi serta membiasakan siswa untuk mengonsumsi sayur dan buah di rumah.
\end{abstract}

Kata kunci: Pedoman gizi seimbang, konsumsi buah, konsumsi sayur

\section{ABSTRACT}

Indonesia is faced with two nutritional problems, namely malnutrition and over nutrition while nutritional problems in adolescents tend to be more dominant for being overweight, this can be seen from the prevalence of adolescent obesity in Cianjur district is $10.6 \%$. Therefore consumption of vegetables and fruits is highly recommended to reduce the prevalence of overweight especially in adolescents. The government through the Indonesian Indonesian Balanced-Nutrition Guidelines (PGS) recommends consumption of vegetables and fruits of $400 \mathrm{~g}$ per person per day consisting of $250 \mathrm{~g}$ of vegetables and $150 \mathrm{~g}$ of fruit. The purpose of this study was to identify the availability of vegetables and fruits at home, the contribution of vegetables and fruit to vitamin, mineral and fiber intake and the relationship between the nutritional practices of students and mothers as parents related to Indonesian Balanced-Nutrition Guidelines with the consumption of vegetables and fruit. This study was a cross-sectional study funded by the Neys-van Hoogstraten Foundation, the Netherlands and conducted at SMPN 1 Cianjur with a total of 72 students. Data were analyzed using Mann Whitney difference test and Rank Spearman relationship test. This research was funded by Neys-van Hoogstraten Foundation, the Netherlands. The amount of fruit and vegetable consumption of students has not been in accordance with Indonesian Balanced-Nutrition Guidelines recommendations. The average of vegetable consumption of students was $36.9 \pm 34.8$ grams per day, while the average of fruit consumption of student was $203.2 \pm 112.9$ grams per day. There was a significant relationship $(p<0.05)$ between maternal nutritional practices and nutritional practices of students related to $P G S$ with consumption of vegetables and fruit of students. This study shows that the consumption of vegetables and fruit in students has not been implemented in accordance with the recommendations of PGS therefore it's need to make encouragement to parents which can motivate and familiarize students to consume vegetables and fruit at home.

Keywords: Balanced nutrition guidelines, fruit consumption, vegetable consumption 


\section{PENDAHULUAN}

Remaja adalah anak yang berusia 10-19 tahun. Kelompok ini termasuk kedalam kelompok usia peralihan dari anak-anak menjadi remaja muda sampai dewasa. Kondisi penting yang berpengaruh terhadap kebutuhan zat gizi kelompok ini adalah pertumbuhan cepat memasuki usia pubertas, kebiasaan jajan, menstruasi dan perhatian terhadap penampilan fisik "Body image" pada remaja puteri. Dengan demikian perhitungan terhadap kebutuhan zat gizi pada kelompok ini harus memperhatikan kondisi-kondisi tersebut. Kondisi seseorang pada masa dewasa banyak ditentukan oleh keadaan gizi dan kesehatan pada masa remaja. Membiasakan pola makan sehat pada remaja menjadi penting sebagai upaya untuk mencegah munculnya masalah-masalah kesehatan pada masa dewasa dan tua nanti. ${ }^{1,2}$

Indonesia dihadapkan pada dua masalah gizi yaitu gizi kurang dan gizi lebih. Prevalensi penduduk Jawa Barat dengan status gizi kurang sebesar $11.0 \%$ hampir sama dengan rata rata nasional yaitu $11.1 \%$. Masalah gizi lebih di Jawa Barat sebesar 11.7\%, angka ini lebih besar dari rata rata nasional yaitu $11.5 \%$, sedangkan penduduk dengan status gizi obesitas di Jawa Barat sebesar $15.2 \%$ lebih tinggi dari rata rata nasional yang sebesar 14.8\%. ${ }^{3}$ Provinsi Jawa Barat memiliki rerata konsumsi sayur dan buah sebesar $47.0 \mathrm{~g} / \mathrm{kap} / \mathrm{hari}$ dan $29.8 \mathrm{~g} / \mathrm{kap} /$ hari di bawah konsumsi nasional yaitu $57.1 \mathrm{~g} / \mathrm{kap} / \mathrm{hari}$ dan $33.5 \mathrm{~g} / \mathrm{kap} / \mathrm{hari}$. Adapun rekomendasi dalam Pedoman Gizi Seimbang (PGS) menurut Badan Kesehatan Dunia (WHO) menganjurkan konsumsi sayuran dan buahbuahan sejumlah $400 \mathrm{~g}$ per orang per hari, yang terdiri dari $250 \mathrm{~g}$ sayur (setara dengan $2 \frac{1}{2}$ porsi atau $2 \frac{1}{2}$ gelas sayur setelah dimasak dan ditiriskan) dan $150 \mathrm{~g}$ buah (setara dengan 3 buah pisang ambon ukuran sedang atau $1 \frac{1}{2}$ potong pepaya ukuran sedang atau 3 buah jeruk ukuran sedang). Sekitar dua-pertiga dari jumlah anjuran konsumsi sayuran dan buah-buahan tersebut adalah porsi sayur. ${ }^{4}$

Penelitian Silva et al., tahun 2016 menyimpulkan bahwa ketersediaan sayur dan buah adalah penghubung antara faktor-faktor lain terhadap konsumsi sayur dan buah. ${ }^{5}$ Menurut Contento tahun 2010 ketersediaan sayur dan buah di rumah berhubungan positif dengan konsumsi sayur dan buah pada remaja. ${ }^{6}$ Kurang konsumsi sayur dan buah dapat menyebabkan tubuh kekurangan gizi seperti vitamin, mineral, serat dan tidak seimbangnya asam basa tubuh, sehingga dapat mengakibatkan timbulnya berbagai penyakit. Penelitian Mittmann et al., tahun 2014 menunjukkan keterlibatan orang tua terhadap perilaku konsumsi sayur dan buah seperti menawarkan sayur dan buah sehari-harinya dan membawakan sayur dan buah sebagai bekal akan berpengaruh terhadap konsumsi sayur dan buah pada anak lebih banyak. ${ }^{7}$ Penelitian Mohammad dan Madanijah tahun 2015 pendidikan ayah dan ibu berhubungan signifikan dengan konsumsi sayur dan buah anak. ${ }^{8}$ Penelitian Sophia dan Madanijah tahun 2014 terdapat kecenderungan bahwa semakin baik pola asuh makan dari ibu terhadap anak, maka semakin banyak jenis buah disukai dan jumlah konsumsi buah pada anak. ${ }^{9}$ Segala sesuatu yang diperoleh dalam bentuk pengetahuan, direspon dalam bentuk sikap dan dicerminkan dalam bentuk praktik. Interaksi antara pengetahuan gizi dan sikap gizi terhadap Pedoman Gizi Seimbang tercermin dari praktik konsumsi pangan. Praktik konsumsi pangan pada dasarnya merupakan bentuk penerapan kebiasaan makan, yang dalam hal ini salah satu pesan yang sangat penting dari Pedoman Gizi Seimbang adalah biasakan konsumsi banyak sayur dan cukup buah. Selama ini belum ada yang menganalisis lebih dalam terkait praktik gizi seimbang khususnya remaja dengan konsumsi sayur dan buahnya. Perlu diketahui bahwa bentuk paling kuat untuk melihat implementasi atau penerapan suatu pesan gizi seimbang adalah dari praktik sekaligus konsumsinya.

Berbagai upaya telah dilakukan pemerintah untuk menurunkan masalah gizi, diantaranya melalui Pedoman Gizi Seimbang yang merupakan bentuk transformasi dari slogan empat sehat lima sempurna dan merupakan panduan dalam konsumsi makan, beraktivitas fisik, perilaku hidup bersih dan sehat serta kebiasaan memantau berat badan yang ideal untuk menjadikan tubuh tetap sehat dan produktif. Selain itu, diperlukan adanya dukungan dan kesadaran dari warga untuk menerapkan prinsip pedoman gizi seimbang dalam kehidupan sehari-hari khususnya pada remaja yang rentan akan masalah gizi. Untuk melihat implementasi dari Pedoman Gizi Seimbang khususnya mengenai konsumsi sayur dan buah pada anak 
sekolah khususnya kelompok remaja, diperlukan adanya penelitian mengenai konsumsi sayur dan buah pada remaja kaitannya dengan praktik siswa serta ibu sebagai orang tua terkait Pedoman Gizi Seimbang. Oleh karena itu penelitian ini bertujuan untuk: 1) mengidentifikasi ketersediaan sayur dan buah di rumah 2) kontribusi sayur dan buah terhadap asupan vitamin, mineral dan serat 3) hubungan antara praktik gizi siswa maupun ibu sebagai orang tua siswa terkait pedoman gizi seimbang dengan konsumsi sayur dan buah siswa.

\section{BAHAN DAN METODE}

Desain penelitian yang digunakan adalah metode cross-sectional. Penelitian ini dilakukan di SMPN 1 Cianjur. Pemilihan lokasi penelitian dilakukan secara purposive (sengaja) dengan pertimbangan diantaranya melihat secara umum sejauh mana pedoman gizi seimbang sudah dikenal berdasarkan lokasi sekolah yaitu di perkotaan. Selain itu, secara karakteristik sekolah, siswa, maupun orang tua siswa yang dirasa mampu secara finansial dan termasuk ke dalam sekolah favorit di Kota Cianjur. Penelitian ini dilaksanakan pada bulan September-Oktober 2018. Penelitian ini merupakan bagian dari penelitian yang berjudul Study of Food Habits and Implementation of Indonesian Dietary Guidelines and Its Impact on Nutritional Status of School Children in Cianjur, Indonesia yang didanai oleh Neys-van Hoogstraten Foundation. Teknik penarikan sampel yang digunakan adalah simple random sampling dengan kriteria inklusi yang ditetapkan adalah siswa kelas VIII SMP dengan pertimbangan bahwa dengan memilih sasaran siswa kelas VIII tidak akan mengganggu kegiatan akademik karena jika kelas IX SMP akan mempersiapkan ujian nasional dan siswa kelas VII SMP sebagai siswa baru masih belum terlalu mengenal lingkungan sekolah, kemudian tinggal bersama ibu, dan bersedia menjadi contoh penelitian. Jumlah sampel minimal pada penelitian ini adalah 37 orang didapatkan melalui perhitungan rumus besar sampel Lemeshow tahun 1990 berdasarkan prevalensi obesitas remaja di Kabupaten Cianjur sebesar $10.6 \%$, sedangkan total subjek pada penelitian ini berjumlah 72 orang siswa.

Jenis data yang terkumpul meliputi karakteristik siswa, yaitu jenis kelamin, usia, uang saku, pendapatan keluarga, data ketersediaan sayur-buah di rumah, konsumsi sayur dan buah (asupan vitamin, mineral dan serat), praktik gizi terkait pedoman gizi seimbang siswa maupun ibu serta antropometri siswa (berat badan dan tinggi badan). Data karakteristik siswa diperoleh melalui wawancara langsung dengan anak menggunakan kuesioner, sedangkan data ibu diperoleh dengan cara self administered questionnare. Kuesioner yang digunakan sudah diuji validitas dan reabilitas. Data ketersediaan sayur dan buah di rumah diperoleh melalui pertanyaan yang menanyakan seberapa sering sayur dan buah tersedia di rumah dalam satu minggu terakhir. Jawabannya adalah jarang (0-2 hari/minggu), kadang-kadang (3-5 hari/ minggu) dan sering (6-7 hari/minggu). Data konsumsi sayur dan buah diketahui melalui metode Semi-Quantitave-Food Frequency Questionnaire (SQ-FFQ) sebanyak 14 jenis buah dan 11 jenis sayur selama satu bulan terakhir berdasarkan studi literatur dari penelitian Fitridina (2013) di Cianjur. Data asupan vitamin, mineral dan serat diperoleh dari hasil olah data menggunakan Tabel Komposisi Pangan Indonesia (TKPI) dan juga Daftar Komposisi Bahan Makanan (DKBM). Berdasarkan hasil SQ-FFQ, kemudian dihitung jumlah dan frekuensi konsumsi sayur dan buah. Jumlah sayur dan buah yang dikonsumsi dalam sehari, selanjutnya dikategorikan menjadi tiga bagian. Kategori jumlah konsumsi buah ditentukan dari ratarata quartil konsumsi buah per orang dalam sehari yaitu kurang dari 50g/hari, 50-100g/hari dan lebih dari $100 \mathrm{~g}$ /hari. Kategori jumlah konsumsi sayur juga ditentukan dari rata-rata quartil konsumsi buah per orang dalam sehari yaitu kurang dari $60 \mathrm{~g} /$ hari, $60-120 \mathrm{~g} /$ hari dan lebih dari $120 \mathrm{~g} /$ hari. Data antropometri yaitu berat badan dan tinggi badan diperoleh melalui pengukuran secara langsung. Berat badan diukur menggunakan timbangan digital dengan merk Camry sedangkan tinggi badan diukur dengan menggunakan staturemeter. Data hasil pengukuran Berat Badan (BB) dan Tinggi Badan (TB) diolah untuk menentukan nilai Z-skor. Penetuan Z-skor dilakukan menggunakan software WHO Anthro plus 2007. Hasil penentuan Z-Skor terhadap masing-masing individu kemudian dibandingkan dengan distribusi baku rujukan WHO/NCHS. Sangat kurus ( $z$ score $<-3 S D$ ), kurus $(-3 \mathrm{SD} \leq z$-score $<-2 \mathrm{SD})$, normal $(-2 \mathrm{SD} \leq$ $z$ score $<1 \mathrm{SD})$, gemuk $(1 \mathrm{SD} \leq z$ score $\leq 2 \mathrm{SD})$, 
obesitas $(z$ score $>2)$. Data praktik gizi terkait Pedoman Gizi Seimbang ibu maupun anak diperoleh dengan cara mengisi kuisioner terkait praktik Pedoman Gizi Seimbang, kemudian jawaban benar akan dipresentasikan lalu dikategorikan menjadi kurang $(<60 \%)$, cukup $(60-80 \%)$ dan baik $(>80 \%)$ (Khomsan 2000).

Proses pengolahan meliputi kegiatan editing, coding, entry, dan cleaning. Pengolahan data dilakukan dengan menggunakan Microsoft Excel 2007 dan dianalisis dengan menggunakan program SPSS version 16.0 for Windows. Analisis univariat dilakukan secara deksriptif untuk menggambarkan sebaran usia, jenis kelamin, uang saku, pendapatan keluarga, ketersediaan sayur-buah, jumlah konsumsi sayur-buah, rataan dan standar deviasi. Data kontribusi sayur dan buah terhadap asupan vitamin, mineral dan serat diperoleh dengan membandingkan asupan sayur dan buah dengan total asupan vitamin, mineral dan serat dalam sehari. Analisis bivariat dengan uji korelasi Rank Spearman dilakukan untuk melihat hubungan antara praktik gizi siswa maupun ibu terkait pedoman gizi seimbang dengan konsumsi sayur dan buah. Penelitian ini telah mendapat persetujuan etik yang berasal dari Komisi Bioetika Penelitian Kedokteran/Kesehatan Fakultas Kedokteran Universitas Islam Sultan Agung Semarang berupa Keterangan Lolos Kaji Etik (Ethical Approval) dengan nomor: No.311/VIII/2018/Komisi Bioetik tanggal 14 September 2018.

\section{HASIL}

Siswa dalam penelitian ini adalah siswa kelas VIII SMP yang terdari dari 32 orang laki-laki $(44.4 \%)$ dan 40 orang perempuan $(55.6 \%)$. Setengah dari siswa yang mengikuti penelitian berusia 14 tahun (50\%). Rata-rata usia siswa yang diteliti berusia 13.9 tahun. Rata-rata uang saku siswa sehari secara keseluruhan adalah sebesar Rp 24.000 dengan uang saku paling sedikit sebesar Rp 12.000 dan paling banyak sebesar Rp 60.000 per hari. Sebanyak 41 orang siswa (57\%) memiliki uang saku kurang dari Rp 24000. Hasil penelitian menunjukkan rata-rata pendapatan keluarga siswa baik laki-laki maupun perempuan yaitu sebesar Rp 6.278 .250 dan sebesar $63.9 \%$ dengan pendapatan keluarga $>$ Rp 3.500 .000 per bulan. Status gizi siswa dikelompokkan menjadi 5 kelompok yai-

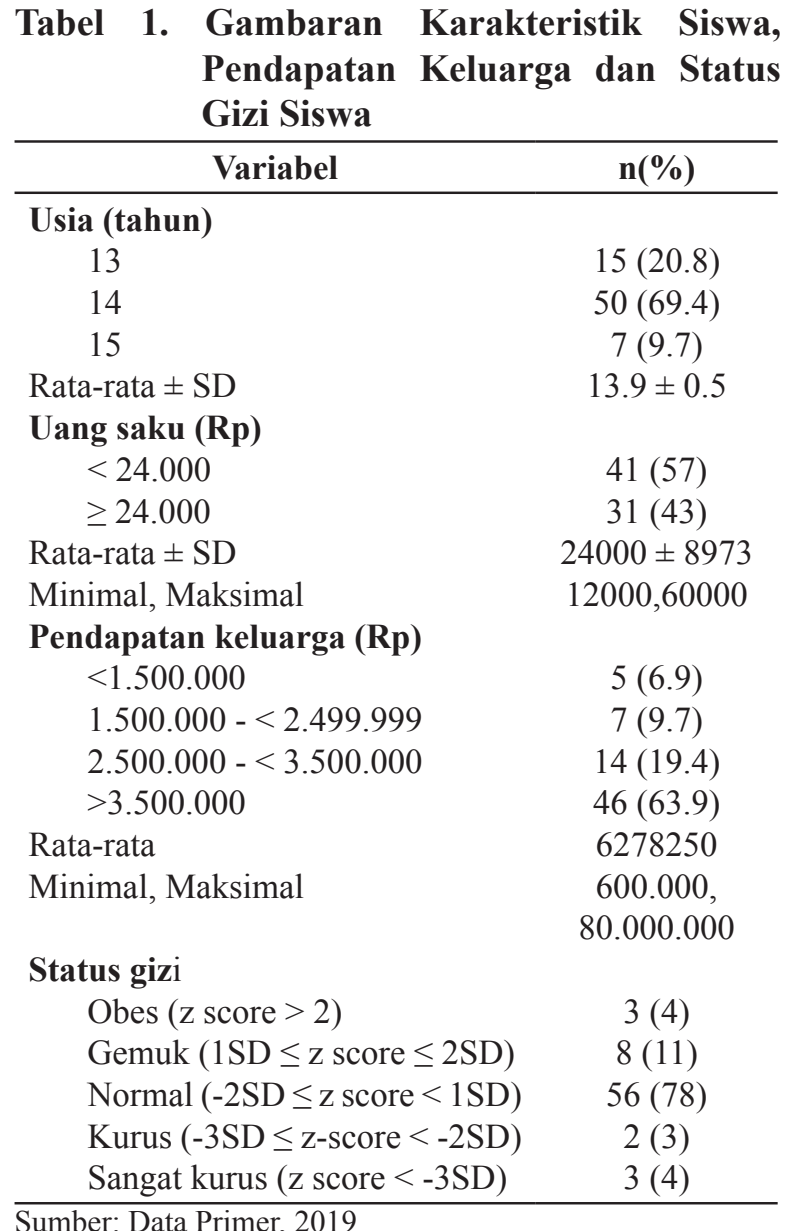

\begin{tabular}{|c|c|}
\hline Variabel & $\mathbf{n}(\%)$ \\
\hline \multicolumn{2}{|l|}{ Ketersediaan sayur di rumah } \\
\hline Jarang (0-2 hari/minggu) & $50(69.4)$ \\
\hline Kadang-kadang (3-5 hari/minggu) & $17(23.6)$ \\
\hline Sering (6-7 hari/minggu) & $5(7.0)$ \\
\hline \multicolumn{2}{|l|}{ Ketersediaan buah di rumah } \\
\hline Jarang $(0-2$ hari/minggu $)$ & $39(54.2)$ \\
\hline Kadang-kadang (3-5 hari/minggu) & $20(27.8)$ \\
\hline Sering (6-7 hari/minggu) & $13(18.0)$ \\
\hline \multicolumn{2}{|l|}{ Jumlah konsumsi sayur } \\
\hline$<60 \mathrm{~g} / \mathrm{hari}$ & $57(79.2)$ \\
\hline $60-120 \mathrm{~g} /$ hari & $11(15.3)$ \\
\hline$>120 \mathrm{~g} / \mathrm{hari}$ & $4(5.5)$ \\
\hline Rata-rata \pm SD & $36.9 \pm 34.8$ \\
\hline \multicolumn{2}{|l|}{ Jumlah konsumsi buah } \\
\hline$<50 \mathrm{~g} /$ hari & $7(9.7)$ \\
\hline $50-100 \mathrm{~g} /$ hari & $8(11.1)$ \\
\hline$>100 \mathrm{~g} / \mathrm{hari}$ & $57(79.2)$ \\
\hline Rata-rata $\pm \mathrm{SD}$ & $203.2 \pm 112.9$ \\
\hline
\end{tabular}

Sumber: Data Primer, 2019 
Tabel 3. Kontribusi Sayur-Buah terhadap Asupan Vitamin, Mineral, dan Serat

\begin{tabular}{lcc}
\hline \multicolumn{1}{c}{ Kategori } & $\begin{array}{c}\text { Rata-rata total konsumsi/ } \\
\text { hari/org }\end{array}$ & \% intake \\
\hline Sayuran & & \\
Vitamin A & 22.16 & 3.69 \\
Vitamin C & 6.72 & 9.54 \\
Asam Folat & 15.99 & 4.00 \\
Fosfor & 15.24 & 1.27 \\
Besi & 0.32 & 1.50 \\
Kalsium & 17.87 & 1.49 \\
Serat & 0.28 & 0.87 \\
Buah-buahan & 11.97 & \\
Vitamin A & 7.92 & 2.00 \\
Vitamin C & 11.26 & 11.61 \\
Asam Folat & 12.42 & 2.81 \\
Fosfor & 0.36 & 1.03 \\
Besi & 12.08 & 1.61 \\
Kalsium & 1.95 & 1.01 \\
Serat & & 5.84 \\
\hline Stion
\end{tabular}

Sumber: Data Primer, 2019

Tabel 4. Praktik Gizi Siswa terkait Pedoman Gizi Seimbang

\begin{tabular}{lc}
\hline \multicolumn{1}{c}{ Praktik Gizi Siswa terkait Pedoman Gizi Seimbang } & n(\%) \\
\hline Kurang $(<60 \%)$ & 0 \\
Sedang $(60-80 \%)$ & $34(47.2)$ \\
Baik $(>80 \%)$ & $38(52.8)$ \\
\hline
\end{tabular}

Sumber: Data Primer, 2019

tu sangat kurus, kurus, normal, gemuk dan obes. Sebagian besar subjek (78\%) memiliki status gizi normal. Masih ditemukan siswa yang memiliki status gizi obes (4\%) dan gemuk (11\%). Sedangkan sisanya memiliki status gizi kurus $(3 \%)$ dan sangat kurus (4\%) (Tabel 1).

Hasil penelitian menunjukkan bahwa sebagian besar (69.4\%) siswa baik siswa laki-laki maupun wanita memiliki ketersediaan sayur di rumah yang tergolong jarang atau sayur hanya tersedia di rumah dalam 1-2 hari per minggu. Sedangkan sisanya memiliki ketersediaan sayur di rumah yang tergolong kadang-kadang (23.6\%) dan sering (7\%). Sama halnya dengan ketersediaan buah di rumah, sebagian besar (54.2\%) siswa baik siswa laki-laki maupun wanita memiliki ketersediaan buah di rumah yang tergolong jarang atau buah hanya tersedia di rumah dalam 1-2 hari per minggu. Sedangkan sisanya memiliki ketersediaan buah di rumah yang tergolong kadang-kadang (27.8\%) dan sering (18\%). Terdapat $5.5 \%$ atau hanya 4 orang siswa yang mengonsumsi sayur lebih dari
120 gram per hari. Sisanya sebanyak $79.2 \%$ atau sebanyak 57 orang siswa mengonsumsi kurang dari $60 \mathrm{~g}$ sayur per hari. Sedangkan kebalikan dari konsumsi sayur, sebanyak $79.2 \%$ atau sebanyak 57 orang siswa mengonsumsi buah lebih dari 100 gram per hari (Tabel 2).

Rata-rata konsumsi sayur secara keseluruhan adalah sebesar $36.9 \pm 34.8$ gram per hari. Sedangkan rata-rata konsumsi buah secara keseluhan adalah sebesar $203 \pm 112.9$ gram per hari. Namun jika digabungkan rata-rata konsumsi sayur dan buah siswa adalah $120.06 \pm 117.9$ gram per hari (Tabel 2). Berdasarkan kontribusi sayur dan buah terhadap asupan vitamin, mineral, dan serat dapat dilihat bahwa total rata-rata secara keseluruhan sayuran dapat memberikan kontribusi vitamin A sebesar 3.69\%, vitamin C 9.54\%, asam folat $4 \%$, fosfor $1.27 \%$, besi $1.50 \%$, kalsium $1.49 \%$, serat $0.87 \%$ terhadap kecukupan vitamin, mineral dan serat sehari, sedangkan buah memberikan kontribusi vitamin A sebesar 2\%, vitamin C $11.61 \%$, asam folat $2.81 \%$, fosfor $1.03 \%$, besi $1.61 \%$, kal- 
sium $1.01 \%$, serat $5.84 \%$ terhadap asupan vitamin, mineral dan serat sehari (Tabel 3).

Praktik gizi siswa terkait Pedoman Gizi Seimbang sebagian besar tergolong baik (52.8\%), sisanya tergolong sedang $(47.2 \%)$ dan tidak ada siswa yang memiliki praktik gizi yang kurang (Tabel 4). Hasil uji hubungan Rank Spearman menunjukkan terdapat hubungan signifikan positif dengan kekuatan korelasi yang lemah antara konsumsi sayur dan buah dengan praktik gizi siswa $(\mathrm{p}=0.024 \mathrm{r}=0.222 ; \mathrm{p}=0.014 \mathrm{r}=0.235)$ maupun ibu $(\mathrm{p}=0.002 \mathrm{r}=0.266 ; \mathrm{p}=0.001 \mathrm{r}=0.361)$ terkait Pedoman Gizi Seimbang. Artinya semakin tinggi praktik terkait Pedoman Gizi Seimbang siswa maupun ibu maka konsumsi sayur dan buahnya akan semakin meningkat (Gambar 1).

\section{PEMBAHASAN}

Gizi Seimbang adalah susunan pangan sehari-hari yang mengandung zat gizi dalam jenis dan jumlah yang sesuai dengan kebutuhan tubuh, dengan memperhatikan prinsip keanekaragaman pangan, aktivitas fisik, perilaku hidup bersih dan mempertahankan berat badan normal untuk mencegah masalah gizi. Praktik seseorang terkait gizi dapat memengaruhi kesehatan dan status gizinya, namun meningkatkan praktik gizi seseorang sulit untuk dilakukan. ${ }^{10}$ Menurut Khomsan et al., tahun 2009 hal ini dikarenakan praktik gizi mung- kin juga dipengaruhi oleh daya beli seseorang, seperti daya beli untuk pangan. Daya beli siswa ditentukan dari uang saku yang diberikan orang tua dalam sehari. Uang saku siswa sehari termasuk dalam kategori kurang dari rata-rata yaitu kurang dari Rp 24.000 (57\%). Melihat pendapatan keluarga yang tergolong besar yaitu lebih dari Rp 3 . 500.000 memungkinkan siswa untuk mendapatkan uang saku yang banyak dari orang tua. ${ }^{11} \mathrm{Na}-$ mun penelitian Bonke tahun 2013 mengatakan besar kecilnya uang saku yang diterima tidak semuanya dipergunakan untuk membeli makanan dan minuman saja, tetapi juga keperluan sekolah dan pribadi seperti membeli mainan, mengumpulkan barang sesuai hobi dan sebagainya. ${ }^{12}$ Uang saku yang dimiliki seseorang akan memengaruhi makanan apa yang dikonsumsi dan frekuensinya. Penelitian lainnya mengatakan bahwa peluang bertambahnya uang saku/jajan yang diterima remaja dari orangtua akan semakin besar dengan semakin meningkatnya daya beli dan pendapatan masyarakat khususnya yang tinggal di daerah perkotaan. ${ }^{13}$ Remaja yang memiliki uang saku cukup besar, biasanya akan lebih sering mengonsumsi makanan modern seperti fast food dan makanan cepat saji lainnya yang memiliki nilai gengsi tinggi di kalangan teman sebaya mereka menurut Estetika tahun $2017 .{ }^{14} \mathrm{Hal}$ ini juga yang menyebabkan masih ditemukannya siswa dengan status gizi obes
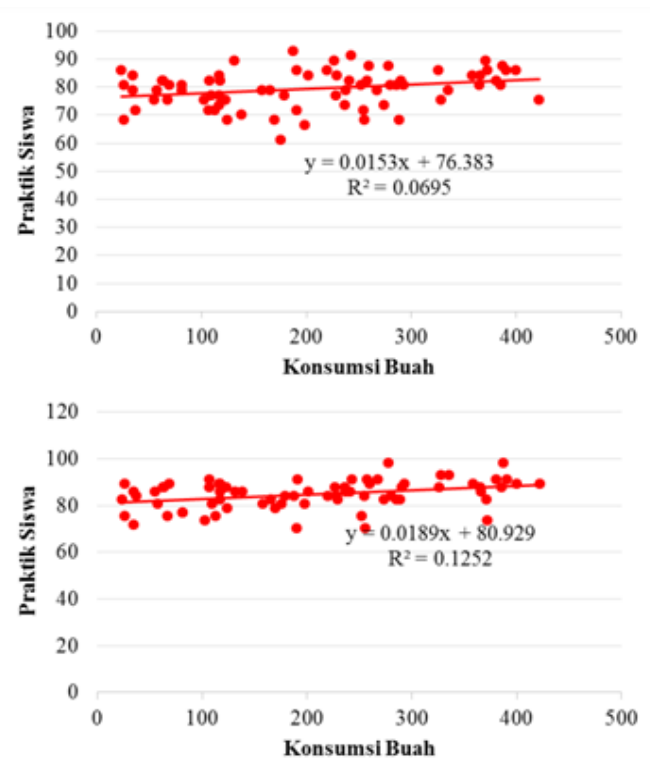

Gambar 1. Kurva Korelasi/Hubungan Praktik Gizi Siswa dan Ibu terkait Pedoman Gizi Seimbang dengan Konsumsi Sayur-Buah 
dan gemuk walaupun secara keseluruhan status gizi siswa tergolong kedalam kategori normal. Sedangkan efek dari konsumsi sayur dan buah sendiri berdasarkan status gizi siswa juga tidak berpengaruh signifikan, hal ini dikarenakan siswa dengan status gizi obes juga mengonsumsi sayur dan buah namun status gizi mereka tetap saja obes. Perlu diketahui bahwa status gizi merupakan hasil akumulasi konsumsi pangan seseorang dalam jangka waktu yang lama sehingga tidak dapat ditarik kesimpulan bahwa dengan konsumsi sayur buah yang meningkat dapat membuat status gizi siswa menjadi normal. Begitu pula sebaliknya siswa setiap harinya tidak menutup kemungkinan juga mengonsumsi pangan tinggi kalori lain dan tidak diimbangi dengan konsumsi sayur dan buah yang sesuai anjuran sehingga status gizinya akan tetap sama walaupun sudah mengonsumsi sayur dan buah.

Ketersediaan sayur dan buah di rumah merupakan salah satu faktor penting yang memengaruhi konsumsi sayur dan buah pada remaja. Ketersediaan sayur dan buah siswa di rumah (69.4\% dan 54.2\%) termasuk ke dalam kategori jarang (1-2 hari/minggu). Hasil ini sejalan dengan penelitiaan Watts et al., tahun 2016 dimana remaja yang memiliki ketersediaan buah dan sayur di rumah rendah, akan mengonsumsi buah dan sayur lebih rendah. ${ }^{15}$ Selain itu Nago et al., tahun 2012 melaporkan remaja yang sekolah di sekolah negeri lebih sedikit yang memiliki buah di rumah setiap harinya. ${ }^{16}$ Hal ini juga didukung oleh penelitian Svastisalee et al., tahun 2012 yang mengungkapkan bahwa ketersediaan sayur dan buah terutama di rumah dapat menjadi faktor yang berpengaruh dalam mencapai tingkat konsumsi sayur dan buah pada remaja. Tingginya ketersediaan dan keterjangkauan sayur dan buah terutama di rumah dapat meningkatkan konsumsi sayur dan buah pada anak usia sekolah. ${ }^{17}$ Penelitian lainnya juga menunjukkan bahwa konsumsi buah dan sayur yang baik lebih banyak pada siswa yang memiliki ketersediaan buah dan sayur yang baik atau sering di rumah. ${ }^{18}$

Konsumsi sayur dan buah merupakan salah satu pesan penting yang terdapat dalam Pedoman Gizi Seimbang dan harus diperhatikan karena sayur dan buah merupakan sumber vitamin, mineral serta serat yang dibutuhkan oleh tubuh.
Terdapat hasil yang bervariasi terkait penelitian tentang konsumsi sayur dan buah. Pada penelitian ini jumlah konsumsi sayur dan buah masih belum memenuhi anjuran WHO yang terkandung dalam Pedoman Gizi Seimbang yaitu sebanyak 400 gram sayur dan buah per hari. ${ }^{19}$ Konsumsi sayur siswa tergolong kurang dengan rata-rata $36.9 \pm 34.8 \mathrm{~g}$ per hari, sedangkan konsumsi buah siswa tergolong baik dengan rata-rata $203.2 \pm 112.9$ g per hari. Hal ini sejalan dengan penelitian Kusumaningrum dan Indrawani tahun 2014 yang menunjukkan bahwa $56.3 \%$ siswa tidak memenuhi anjuran konsumsi sayur dan buah sebanyak 400 gram per orang per hari. ${ }^{20}$ Didukung juga oleh penelitian Anggraeni \& Sudiarti tahun 2018 yang dilakukan di SMP Negeri 98 Jakarta, rata-rata konsumsi buah dan sayur hanya sebesar $85.13 \pm 26.58$ gram/hari. ${ }^{21}$ Penelitian Hermina dan Prihatini tahun 2016 juga menyebutkan bahwa konsumsi buah dan sayur penduduk Indonesia usia 13-18 tahun sebanyak 108.8 gram/ orang/hari..$^{22}$ Namun, hal ini tidak sejalan dengan penelitian Farisa tahun 2012 di SMP Negeri 8 Depok yang menunjukkan bahwa rata-rata konsumsi buah dan sayur sebanyak 512.4 gram/hari yang berarti sudah mengikuti anjuran konsumsi sayur dan buah sebanyak 400 gram per orang per hari. ${ }^{18}$ Hasil yang bervariasi ini disebabkan oleh beberapa faktor seperti ketersediaan sayur dan buah baik di rumah maupun di sekolah, preferensi siswa terhadap sayur dan buah sendiri, serta keterlibatan orang tua dalam mengawasi anak saat mengonsumsi sayur dan buah.

Kandungan gizi yang cukup menonjol pada buah-buahan dan sayuran adalah vitamin, mineral dan serat menurut Dave et al., tahun $2010 .{ }^{23}$ Kontribusi sayur dan buah terhadap asupan vitamin dan mineral sangatlah penting. Beberapa vitamin dan mineral yang tinggi kandungannya pada sayur dan buah seperti vitamin A, vitamin C, asam folat, fosfor, besi, dan kalsium diperoleh dari perbandingan antara asupan vitamin, mineral dan serat yang berasal dari konsumsi makan sehari terhadap total keseluruhan asupan vitamin, mineral dan serat sehari. Gambaran sayur dan buah terhadap kontribusi asupan vitamin dan mineral erat kaitannya dengan kuantitas atau banyaknya jumlah konsumsi sayur dan buah dalam sehari. Terlihat bahwa konsumsi buah siswa dalam sehari secara keseluruhan lebih banyak daripada konsumsi sayur. Hasil penelitian 
ini juga menunjukkan bahwa kontribusi vitamin dan mineral tidak sebanding dengan kebutuhan vitamin dan mineral yang dianjurkan dalam sehari. Hal ini diduga karena pola konsumsi sayur dan buah yang terhitung jarang dan belum menjadi suatu rutinitas wajib yang harus dikonsumsi setiap harinya. Kurangnya ketersediaan sayur dan buah di rumah juga diduga menjadi hal penting yang memengaruhi kurangnya asupan vitamin dan mineral tersebut. Namun serat yang berasal dari konsumsi buah sudah sebanding dengan kebutuhan yang dianjurkan dalam sehari sebesar $37.55 \%$. Hasil ini sejalan dengan penelitian Vuholm tahun 2014 menunjukkan bahwa buah dan sayur berkontribusi terhadap asupan serat harian sebesar lebih dari $30 \% .^{24}$

Praktik gizi siswa dalam penelitian ini sebagian besar termasuk kategori baik. Hal ini menunjukkan bahwa sebagian besar siswa sudah mempraktikan dengan baik terkait pesan-pesan yang terkandung dalam Pedoman Gizi Seimbang dalam kehidupan sehari-hari. Penelitian ini juga menunjukkan terdapat hubungan positif yang signifikan $(\mathrm{p}<0.05)$ antara konsumsi sayur dan buah dengan praktik gizi siswa maupun ibu terkait PGS. Hal ini berarti semakin baik praktik gizi terkait Pedoman Gizi Seimbang semakin baik pula konsumsi sayur dan buah siswa. Hasil ini berbeda dengan penelitian Fibrihirzani tahun 2012, serta Mohammad \& Madanijah tahun 2015 yang mengungkapkan bahwa yang berhubungan signifikan adalah pengetahuan gizi dan sikap gizi siswa dengan konsumsi buah dan sayur. ${ }^{8,25}$ Hasil yang berbeda ini kemungkinan terjadi karena kebiasaan konsumsi sayur dan buah yang masih kurang. Walaupun pengetahuan, sikap dan praktik yang dimiliki siswa tergolong baik, hal tersebut tidak akan berpengaruh besar jika siswa memang tidak dibiasakan konsumsi sayur dan buah baik di lingkungan keluarga maupun di lingkungan sekolah. Praktik gizi bukanlah satu-satunya hal yang dapat memengaruhi konsumsi sayur dan buah siswa melainkan ada faktor lain seperti ketersediaan pangan, pendapatan, daya beli, dan juga kebiasaan makan. Penelitian Permatasari, tahun 2013 menyatakan praktik gizi seseorang erat kaitannya dengan pengetahuan gizi serta sikap gizi orang tersebut. Selain itu penelitian lain menyebutkan bahwa seseorang yang terpapar informasi gizi cenderung memiliki praktik terkait gizi yang lebih baik. ${ }^{26}$ Freisling et al. (2009) Berdasarkan hal tersebut dapat disimpulkan bahwa pengetahuan dan sikap gizi bukanlah kunci utama yang memengaruhi siswa dalam mengonsumsi sayur dan buah. Tetapi hal terpenting adalah praktiknya langsung atau implementasi dari pengetahuan gizi dan sikap gizi yang dimiliki oleh siswa tersebut. ${ }^{27}$

\section{KESIMPULAN DAN SARAN}

Penelitian ini menyimpulkan bahwa ketersediaan sayur dan buah siswa di rumah tergolong jarang atau hanya tersedia dalam 1-2 hari per minggu. Hal ini diduga karena kurangnya keterlibatan orang tua maupun anggota keluarga yang bertanggung jawab terhadap penyajian dan ketersediaan makanan juga diperlukan dalam upaya peningkatan konsumsi buah dan sayur siswa. Hal tersebut erat juga kaitannya dengan pendapatan keluarga yang sangat tinggi dirasa mempunyai daya beli yang tinggi juga terhadap sayur dan buah tetapi hal tersebut tidak menjamin tersedianya sayur dan buah di rumah. Hasil penelitian ini juga menunjukkan bahwa kontribusi vitamin dan mineral tidak sebanding dengan kebutuhan vitamin dan mineral yang dianjurkan dalam sehari. Hal ini diduga karena pola konsumsi sayur dan buah yang terhitung jarang dan belum menjadi suatu rutinitas wajib yang harus dikonsumsi setiap harinya. Namun serat yang berasal dari konsumsi buah sudah sebanding dengan kebutuhan yang dianjurkan dalam sehari. Semakin tinggi praktik terkait Pedoman Gizi Seimbang siswa maupun ibu maka konsumsi sayur dan buahnya akan semakin meningkat. Konsumsi sayur dan buah sangat penting, sehingga perlunya pengawasan orang tua di rumah dalam hal konsumsi sayur dan buah anak, dan cenderung menyediakan sayur dan buah yang disukai anak di rumah. Diharapkan juga adanya usaha peningkatan konsumsi sayur dan buah dari pihak terkait terutama di bidang gizi dan kesehatan seperti puskesmas yang bekerjasama dengan pihak sekolah. Usaha dilakukan mulai dari hal kecil seperti menempel poster terkait konsumsi sayur dan buah di tempat yang mudah diakses oleh siswa sehingga siswa menjadi teringat tentang pesan yang terkandung dalam poster tersebut dan dapat memberikan stimulus untuk mengonsumsi sayur dan buah. 


\section{UCAPAN TERIMA KASIH}

Penulis mengucapkan terimakasih kepada Neys-van Hoogstraten Foundation, the Netherlands yang telah mendanai penelitian ini.

\section{DAFTAR PUSTAKA}

1. Neumark-sztainer D, Bruening $M$, Eisenberg M, MacLehose R, Nanney MS, Story M, Neumark-sztainer D. Relationship Between Adolescents' and Their Friends' Eating Behaviors: Breakfast, Fruit, Vegetable, Whole-Grain, and Dairy Intake. J Acad Nutr Diet. 2012;112(10): 1608-1621.

2. Nurhayati A. Status Gizi, Kebiasaan Makan dan Gangguan Makan (Eating Disorder) pada Remaja di Sekolah Favorit dan Non-Favorit. Media Gizi dan Keluarga. 2010;6(3):124-126.

3. Kementerian Kesehatan RI. Laporan Nasional Riset Kesehatan Dasar (Riskesdas). Jakarta: Badan Penelitian dan Pengembangan Keseha$\tan ; 2013$.

4. [BPS] Badan Pusat Statistik. Cianjur Dalam Angka Tahun 2017. Kabupaten Cianjur: BPS Balitbangkes. 2014. Survey Konsumsi Makanan Individu:Studi Diet Total (SDT) 2014. Kementerian Kesehatan RI; 2017.

5. Silva FM, Smith-Menezes A, Duarte M. Consumption of Fruits and Vegetables Associated with Other Risk Behaviors among Adolescents In Northeast Brazil. Rev Paul Pediatr. 2016;34(3):309-324.

6. Contento. Fruit and Vegetable Enables Adolescent Consumption that Exceeds National Average. Nutritional Research. 2010; 3(3):369-402.

7. Mittmann S, Austel A, Ellrot T. Determinants of Fruit and Vegetable Consumption in Primary School Children. Ernahrungs Umschau. 2014;61(8):124-129.

8. Mohammad A \& Madanijah S. Konsumsi Sayur dan Buah Anak Usia Sekolah Dasar di Bogor. Jurnal Gizi Pangan. 2015;10(1):71-76.

9. Sophia A \& Madanijah S. Pola Asuh Makan Ibu serta Preferensi dan Konsumsi Sayur dan Buah Anak Usia Sekolah di Bogor. Jurnal Gizi Pangan. 2014;9(3):151-158.

10. Mawaddah N, Hardinsyah. Pengetahuan, Sikap dan Praktik Gizi serta Tingkat Konsumsi Ibu Hamil di Kelurahan Kramat Jati dan
Kelurahan Ragunan Propinsi DKI Jakarta. Jurnal Pangan dan Gizi. 2008;3(1):30-42.

11. Khomsan A, Faishal A, Mudjajanto Eddy S. Pengetahuan, Sikap, dan Praktek Gizi Ibu Peserta Posyandu (Nutritional Knowledge, Attitude and Practice Of Posyandu Participants). Jurnal Gizi Pangan. 2009;4(1):33-41.

12. Bonke J. Do Danish Children and Young People Receive Pocket Money? Copenhagen (DK): Rockwool; 2013.

13. Bahria dan Triyanti. Faktor-Faktor yang terkait dengan Konsumsi Buah dan Sayur pada Remaja di 4 SMA Jakarta Barat. Jurnal Kesehatan Masyarakat. 2010;4(2):63-71.

14. Estetika. Faktor yang Berhubungan dengan Frekuensi Konsumsi Fast Food pada Mahasiswa. Jurnal Gizi Klinik Indonesia. 2017; 14(2):135-144.

15. Watts DE, Least C, Gromis J, Lohse B. Nutrition Education Intervention Improves Vegetable-Related Attitude, Self-Efficacy, Preference, and Knowledge of Fourth-Grade Students. Journal of School Health. 2016;82(1):37-43.

16. Nago, E. S. Food Safety is a Key Determinant of Fruit and Vegetable Consumption in Urban Beninese Adolescents. J Nutr Educ Behav. 2012;44(6):548-555.

17. Svastisalee, C., Holstein, B. \& Due, P. Fruit and Vegetable Intake in Adolescents: Association with Socioeconomic Status and Exposure to Supermarkets and Fast Food Outlet. J Nutr Metab. 2012;1-9.

18. Farisa. Hubungan Sikap, Pengetahuan, Ketersediaan dan Keterpaparan Media Massa dengan Konsumsi Buah dan Sayur Pada Siswa SMPN 8 Depok Tahun 2012 [Skripsi]. Jakarta: Universitas Indonesia; 2012.

19. Kementerian Kesehatan RI. Pedoman Gizi Seimbang: Pedoman Teknis Bagi Petugas Dalam Memberikan Penyuluhan Gizi Seimbang. Jakarta: Kementerian Kesehatan RI; 2014.

20. Kusumaningrum Maria D, Indrawani Yvonne M. Perbedaan Proporsi Ketersediaan Sayur dan Buah di Rumah dan Faktor Lainnya terhadap Konsumsi Sayur dan Buah Siswa SDN Jatirahayu VIII Bekasi Tahun 2014 [Skripsi]. Jakarta: Universitas Indonesia; 2014.

21. Anggraeni Nur A, Sudiarti T. Faktor Dominan Konsumsi Sayur dan buah pada Remaja di 
SMPN 98 Jakarta. Indonesian Journal of Human Nutrition. 2018:5(1):18-32.

22. Hermina, Prihatini S. Gambaran Konsumsi Sayur dan Buah Penduduk Indonesia dalam Konteks Gizi Seimbang: Analisis Lanjut Survei Konsumsi Makanan Individu (SKMI) 2014. Buletin Penelitian Kesehatan. 2016; 44(3):205-218.

23. Dave JM, Evans AE, Pfeiffer KA, Watkins KW, Saunders RP. Correlates of Availability and Accessibility of Fruits and Vegetables in Homes of Low-Income Hispanic Families. Health Educ Res. 2010;25(1):97-108.

24. Vuholm S, Lorenzen JK, Kristensen M. Relative Validity and Reproducibility of a Food Frequency Questionnaire to Assess Dietary Fiber Intake in Danish Adults. Food \& Nutrition Research. 2014;58(24723):1-7.
25. Fibrihirzani H. Hubungan Antara Karakteristik Individu, Orang Tua dan Lingkungan dengan Konsumsi Sayur dan Buah pada Siswa SDN Beji 5 dan 7 Depok tahun 2012 [Skripsi]. Depok (ID): Universitas Indonesia; 2012.

26. Permatasari. Hubungan Pengetahuan, Sikap dan Praktik Gizi Ibu dengan Konsumsi Pangan Sumber Yodium dan Penggunaan Jenis Garam Rumah Tangga di Wilayah Pegunungan Kabupaten Cianjur [Tesis]. Bogor (ID): Institut Pertanian Bogor; 2013.

27. Freisling H, Haas K, Elmadfa I. Mass Media Nutrition Information Sources and Association Fruit and Vegetable Consumption among Adolescents. Public Health Nutrition. 2009; 13(2):269-275. 